http://dx.doi.org/10.18778/1509-877X.2018.03.01

Artykuły

Adam Mariański*

\title{
KRÓTKA HISTORIA OPODATKOWANIA DOCHODU
}

Streszczenie. W artykule przedstawiono krótką historię opodatkowania podatkiem dochodowym od osób fizycznych. Pokazano ideę opodatkowania dochodu, a następnie zwiększania stawek podatkowych oraz progresywnego opodatkowania osób o wyższych dochodach. Pozwoliło to na wskazanie źródeł zasady zdolności płatniczej, która współcześnie uznawana jest za podstawową ideę realizującą zasadę sprawiedliwego opodatkowania. Sprawiedliwość społeczna ma być realizowana poprzez redystrybucję dochodu. Prowadzi to jednak do coraz większego upolitycznienia podatków dochodowych.

Słowa kluczowe: opodatkowanie dochodu, progresja podatkowa, zasada zdolności płatniczej

1. WPROWADZENIE

We współczesnych systemach podatkowych podatki dochodowe mają duże i ciągle rosnące znaczenie ${ }^{1}$. Rola tego typu podatków nie jest związana tylko z wysokością wpływów budżetowych, które nieznacznie różnią

* Doktor habilitowany nauk prawnych, profesor nadzwyczajny w Katedrze Prawa Podatkowego UŁ, przewodniczący Krajowej Rady Doradców Podatkowych, partner zarządzający w Mariański Group, e-mail: amarianski@marianskigroup.pl

${ }^{1}$ N. Gajl, Modele podatkowe. Podatki dochodowe, Warszawa 1995; A. Mariański, D. Strzelec, Podatki dochodowe, [w:] Zagadnienia ogólne prawa podatkowego, red. W. Nykiel, M. Wilk, Łódź 2014, s. 95-105; R. Zajdler, Opodatkowanie dochodów osób fizycznych w regulacjach prawnych Unii Europejskiej, Warszawa 2002; K. Wach, Systemy podatkowe krajów Unii Europejskiej, Warszawa 2005; Opodatkowanie działalności gospodarczej w Polsce, red. A. Mariański, A. Krajewska, A. Nowak-Piechota, M. Wilk, Warszawa 2016; Prawo podatkowe przedsiębiorców, red. H. Litwińczuk, P. Karwat, A. Kaznowski, W. Pietrasiewicz, K. Tetłak, Warszawa 2013. 
się w poszczególnych dekadach. Sprawiedliwe opodatkowanie podatkami dochodowymi stało się centralnym punktem polityki w poszczególnych państwach $^{2}$, a także na arenie międzynarodowej ${ }^{3}$. $Z$ podejrzliwością wręcz traktuje się państwa bez podatków dochodowych, nawet gdy ich dochody budżetowe nie są oparte tylko na wpływach podatkowych ${ }^{4}$. W stosunku do innych państw lub terytoriów nakłada się różnego rodzaju sankcje za stosowanie $^{5}$ tzw. szkodliwej konkurencji podatkowej. Taka sytuacja ma miejsce nawet wtedy, gdy dla rozwoju gospodarczego i społecznego danego kraju nie jest potrzebne opodatkowanie podatkami dochodowymi.

Większość podatników nie zdaje sobie jednak sprawy, jak krótką historię ma opodatkowanie dochodów, zwłaszcza z wysokimi stawkami, ze szczególnym uwzględnieniem progresji podatkowej. Nowe pokolenia rodzą się w świecie zdominowanym przez przekaz o znaczeniu opodatkowania, szczególnie wysokich dochodów, potrzebie wyrównywania tychże, czy w końcu zmniejszania nierówności poprzez sprawiedliwą redystrybucję dochodów. Podatek dochodowy stał się czymś naturalnym, a dyskusja o potrzebie sprawiedliwego opodatkowania weszła na agendę spotkań nie tylko prawników czy ekonomistów, ale wszystkich obywateli. Osoby postulujące zniesienie opodatkowania dochodu uznaje się za odmieńców, a ich poglądy za przykład irracjonalnej debaty.

Należy jednak rozważyć, czy prowadzone są poważne analizy dotyczące konieczności opodatkowania podatkiem dochodowym, a zwłaszcza dotyczące zasad jego wymiaru. W debacie zarówno naukowej, jak i obywatelskiej brakuje dyskusji o pojęciu dochodu, kwotach wolnych od opodatkowania, ulgach i zwolnieniach podatkowych, a także o tym, jakie powinny być stawki tego podatku. W tym ostatnim kontekście nie prowadzi się szerszych analiz przyczyn progresywnego opodatkowania osób o wyższych dochodach. Temat zostaje najczęściej wyczerpany przez odwołanie się do zasady zdolności płatniczej jako oczywistego aksjomatu.

${ }^{2}$ O niekończących się dyskusjach na temat konieczności opodatkowania bogatych w Stanach Zjednoczonych zob. np. J. Goldberg, Why 'Tax the Rich' demands are so unreasonable, „National Review” 12.04.2019.

3 M. Leconte, M. Raińczuk, Konwencja Wielostronna (BEPS działanie nr 15) - omówienie najistotniejszych zagadnień, „Monitor Podatkowy” 2017, nr 5, s. 16 i n.

${ }^{4}$ Na przykład kraje z dużymi zasobami złóż naturalnych, jak Zjednoczone Emiraty Arabskie.

5 J. Głuchowski, Oazy podatkowe, Warszawa 1996. 
Wystarczy zatem powołać się na twierdzenie, zgodnie z którym we współczesnej doktrynie prawa podatkowego powszechnie przyjmuje się, że zasada zdolności płatniczej jest niekwestionowanym fundamentem, stając się treścią norm prawnych kształtujących wysokość obciążeń podatkowych ${ }^{6}$. Zyskała ona taką rangę, że w niektórych krajach podnoszona jest do zasady konstytucyjnej ${ }^{7}$. Podobne próby wywodzenia podstawy konstytucyjnej dla tej zasady ${ }^{8}$, a nawet progresywności opodatkowania, podejmowane są w Polsce9.

Konieczne jest jednak zastanowienie się nad wieloma zagadnieniami związanymi z opodatkowaniem dochodu opartym na zasadzie zdolności płatniczej. Dlaczego i kiedy zasada ta stała się aksjomatem? W jaki sposób weszła do kanonu zasad opodatkowania i czy nie ma innych alternatywnych rozwiązań? Ponadto czy pozwala dowolnie kształtować obciążenia podatkowe? Zwłaszcza czy dopuszczalne jest nierówne opodatkowanie w ujęciu pionowym?

To tylko niektóre dylematy, których nie uda się rozwiązać w jednym opracowaniu. Poznanie tła historycznego pozwoli nam jednak zastanowić się nad źródłem zasady zdolności płatniczej i jej celami w prawie podatkowym. Niemniej należy także postawić pytanie, czy zasada ta nie stała się przedmiotem manipulacji politycznej. Jakie znaczenie ma dla polityków w krajach demokracji liberalnej?

Odpowiedź na te i wiele innych pytań stanowi centralny punkt w ocenie, czy system podatkowy jest sprawiedliwy. Nie ma co ukrywać, że dyskusja o zasadzie sprawiedliwości podatkowej zawsze będzie naznaczona ideologią osoby formułującej koncepcję tejże zasady ${ }^{10}$. Próba dokonania obiektywnej oceny systemu podatkowego będzie zawsze zgodna $\mathrm{z}$ subiektywną oceną dokonującej jej osoby. Dlatego nie można mówić o powszechnie akceptowanej formule zasady sprawiedliwości. Tym bardziej że sprawiedliwość nie jest wyłącznie normatywnym standardem ${ }^{11}$. Nie cho-

${ }^{6}$ A. Nita, Teoretyczne $i$ normatywne wyznaczniki sprawiedliwego opodatkowania, „Toruński Rocznik Podatkowy” 2013, s. 23; Polskie prawo podatkowe, red. W. Nykiel, Warszawa 2018, s. 26; A. Gomułowicz, Zasada sprawiedliwości podatkowej, Warszawa 2001, s. 59.

${ }^{7}$ K. Tipke, J. Lang, Steuerrecht, Köln 1991, s. 58.

8 A. Nita, op. cit., s. 25.

9 Odmiennie: W. Nykiel, A. Mariański, Komentarz do art. 217, [w:] Konstytucja RP, t. 2: Komentarz do art. 87-243, red. M. Safjan, L. Bosek, Warszawa 2016.

10 A. Nita, op. cit., s. 16.

${ }^{11}$ K. Scheve, D. Stasavage, Taxing the Rich: A History of Fiscal Fairness in the United States and Europe, Princeton 2016, s. 4. 
dzi tylko o to, jak projektodawcy oceniają stosowane regulacje. W opinii obywateli, zwłaszcza podatników, opodatkowanie powinno być sprawiedliwe ${ }^{12}$. Przy czym rzadko kiedy podatnicy posiadają wystarczający zasób wiedzy i doświadczenia, aby ocenić, czy konkretne rozwiązania są sprawiedliwe. Dlatego ich oceny najczęściej dotyczą norm oddziałujących na ich sytuację osobistą: kwota wolna od opodatkowania, ulgi i zwolnienia podatkowe, stawki podatkowe itp.

Problem sprawiedliwego opodatkowania jest szczególnie często i z wielką chęcią podejmowany w ocenach podatków dochodowych. W tym artykule nie jest jednak możliwe odniesienie się do tego zagadnienia. Wymaga to bowiem znacznie szerszych analiz, które zostaną dokonane w kolejnych publikacjach. Niemniej pierwsze wnioski można już wyciągnąć, analizując historię podatku dochodowego, opodatkowania bogatych i fundamentalizmu zasady zdolności płatniczej.

\section{KRÓTKA HISTORIA PODATKU DOCHODOWEGO}

Jak już zaznaczałem, w debacie o podatku dochodowym od osób fizycznych pomijane jest tło historyczne pojawienia się zasady zdolności płatniczej, zwłaszcza konieczności różnicowania opodatkowania, a w szczególności progresywności podatków dochodowych. Do XVIII w. dominowały podatki majątkowe, głównie obciążające nieruchomości ${ }^{13}$.

Podatek dochodowy pojawił się po raz pierwszy w Anglii w 1799 r., choć dopiero po przebudowie w latach 1816 i 1842 stał się istotnym źródłem dochodów publicznych. Początkowo był płacony powyżej kwoty wolnej od opodatkowania, która wynosiła trzykrotność średniego rocznego dochodu (60 funtów), a maksymalna stawka 10\% dotyczyła dochodów powyżej 200 funtów. W 1802 r. został zniesiony, ale potrzeby wydatków powojennych spowodowały jego przywrócenie w kolejnym roku, lecz ze zredukowaną stawką maksymalną do 5\%, z jedoczesnym obniżeniem kwoty wolnej od podatku do 50 funtów. Dla Anglików był on tak ohydnym ciężarem $^{14}$, że po zakończeniu wojen napoleońskich został w 1816 r. zniesiony. Powszechnie uważano go za znaczące ograniczenie wolności, własności i nieuzasadnione naruszenie zasady ochrony życia prywatnego obywateli.

12 S.M. Sheffrin, Tax Fairness and Folk Justice, Cambridge 2013.

13 F.H.M. Grapperhaus, Opowieści podatkowe, Toruń 2000, s. 57 i n.

14 A. Rabushka, Od Adama Smitha do bogactwa Ameryki, Warszawa 1996, s. 59. 
Już jednak w 1840 r. dla zrównoważenia budżetu został tymczasowo przywrócony podatek dochodowy. Był to podatek z niską stawką 3\% od dochodów ponad sześciokrotnie przewyższających średnią krajową (powyżej 150 przy 24 funtach średniego dochodu). Najpierw był wprowadzony na cztery lata, przedłużony na kolejne, a potem nowe wyzwania wojenne spowodowały porzucenie obietnicy tymczasowości, a nawet skutkowały wzrostem stawki do 6\% i obniżaniem progów opodatkowania. Sami propagatorzy jego wprowadzenia obawiali się, że stanie się on stałym elementem systemu budżetowego Anglii, co mogłoby prowadzić do rozrostu rządu ${ }^{15}$. I tak rzeczywiście się stało, gdyż wraz z rosnącymi podatkami dochodowymi rozbudowywane były zadania państwa, a tym samym wzrastały nieustannie potrzeby pozyskania funduszy na ich finansowanie.

Podatek w Anglii został wprowadzony na stałe, a stawka podatkowa w 1918 r. osiągnęła 30\%, wpływy budżetowe zaś tylko w ciągu 25 lat zwiększyły się ponad dwudziestopięciokrotnie krotnie. Po I wojnie nieznacznie obniżono stawkę do $20 \%$, ale potem już stawki systematycznie rosły, aby w trakcie II wojny światowej osiągnąć najpierw $40 \%$, a potem $50 \%$. Najwyższa stawka została nieznacznie zmniejszona po wojnie - do $45 \%$.

W angielskiej historii charakterystyczna jest przyczyna zwiększania obciążeń podatkowych: stawki rosną w okresach wojennych, ale także w związku z rozrostem funkcji państwa, w tym zwłaszcza socjalnych. Przy czym po zakończeniu wojen poszukiwano innego uzasadnienia dla opodatkowania dochodów, zwłaszcza osób bogatych. Do tego zagadnienia jeszcze powrócę.

W innych krajach europejskich podatek dochodowy został wprowadzony znacznie później. Szczątkowe regulacje pojawiały się w Danii w 1870 r. oraz w Prusach w roku 1891. W innych krajach jego nałożenie również związane było z prowadzonymi wojnami, np. we Francji, Holandii (1914) czy Belgii (1919).

W Polsce na stałe zagościł po odzyskaniu niepodległości. Ustawa z dnia 16 lipca 1920 r. o państwowym podatku dochodowym ${ }^{16}$ była wzorowana na odpowiednim podatku pruskim. Doprowadziła ona do unifikacji podatków bezpośrednich w II Rzeczpospolitej. Akt ten był wielokrotnie nowelizowany, ale opodatkowanie dochodów utrzymano do wybuchu II wojny światowej. Po 1945 r. w PRL wprowadzano różnego rodzaju podatki

\footnotetext{
15 Ibidem, s. 82.

16 Dz.U. z 1920 r., Nr 82, poz. 550.
} 
dochodowe i przychodowe; jednolity podatek dochodowy został przywrócony po $1989 \mathrm{r.}^{17}$

W Stanach Zjednoczonych podatek dochodowy wprowadzono w $1861 \mathrm{r}$. w związku z wojną domową. Opodatkowany był jednak dochód jedynie powyżej 600000 dolarów, a stawki były progresywne, najpierw 3\% i 5\%, a potem 5\% i 10\%. Został on zlikwidowany w 1872 r. Ponownie wprowadzony w 1894 r. podatek został rok później uznany przez Sąd Najwyższy za sprzeczny z Konstytucją.

Dopiero po ratyfikowaniu XVI Poprawki do Konstytucji ${ }^{18}$ został on definitywnie ustanowiony w 1913 r., lecz obejmował zaledwie kilka procent populacji, a stawki wynosiły od $1 \%$ do $7 \%$ dochodu. Progresja podatkowa rosła w okresie I wojny światowej, co w latach dwudziestych XX w. doprowadziło do stawki $25 \%$. W okresie wielkiego kryzysu następuje systematyczny wzrost podatku, aby osiągnąć stawkę 77\%. Podczas II wojny światowej wielkość ta przekracza 90\%. Ten poziom opodatkowania stabilizuje się do lat sześćdziesiątych. W okresie 1932-1980 najwyższa stawka federalnego podatku dochodowego w USA wynosiła średnio $81 \%{ }^{19}$.

\section{SPRAWIEDLIWOŚĆ PODATKOWA}

Możemy wyróżnić sprawiedliwość poziomą i pionową. Pierwsza polega na nakładaniu takiego samego obciążenia na podmioty, które znajdują się w takiej samej sytuacji ${ }^{20}$. Natomiast sprawiedliwość pionowa oznacza odmienne traktowanie podmiotów znajdujących się w różnych sytuacjach. Tak zdefiniowana sprawiedliwość nie budzi wątpliwości teoretycznych, jako pewien model. Dopiero jednak zbadanie tych założeń w konkretnych systemach podatkowych pozwoli odpowiedzieć na pytanie, czy została zrealizowana zasada sprawiedliwości podatkowej ${ }^{21}$.

17 Szerzej R. Mastalski, Prawo podatkowe, Warszawa 2018, s. 371 i n.

18 W literaturze podnosi się, że poprawka ta została wprowadzona nielegalnie - zob. W. Kwaśnicki, $Z$ historii podatku dochodowego, http://kwasnicki.prawo.uni. wroc.pl/todownload/Historia\%20podatku\%20doch.pdf (dostęp: 15.08.2019).

19 T. Piketty, Kapitał w XXI wieku, Warszawa 2015, s. 631.

20 Polskie prawo podatkowe, s. 24

${ }^{21}$ Zagadnienie to będzie szeroko omawiane w kolejnych opracowaniach, np. A. Mariański, Źródła przychodów - niesprawiedliwe i skomplikowane różnicowanie opodatkowania osób fizycznych, „Przegląd Ustawodawstwa Gospodarczego” (w druku). 
Sprawiedliwość pozioma winna być fundamentalnym założeniem każdego społeczeństwa ${ }^{22}$. Ponieważ każdy jest równy wobec prawa, to nie może być inaczej traktowany na gruncie prawa podatkowego. Przy czym odrzuca się sprawiedliwość formalną, czyli nieuwzględniającą sytuacji życiowej podatników ${ }^{23}$. Przyjmuje się, że byłaby to równość pozorna, nie dla wszystkich bowiem taki sam podatek oznacza takie samo obciążenie. Podatnik z większym dochodem ponosiłby mniejszy ciężar niż osoba uboższa. Dla uznania tej tezy za prawdziwą musimy jednak przyjąć takie same zdolności i preferencje.

Odrzucając sprawiedliwość formalną na gruncie prawa, dodaje się nakaz traktowania w jednakowy sposób jednostek należących do tej samej kategorii ${ }^{24}, \mathrm{w}$ ten zatem sposób rozpoczyna się przygotowanie uzasadnienia dla wprowadzania zmian wynikających ze sprawiedliwości pionowej. Ma to jakoby także zaletę nieograniczania ustawodawcy w zakresie określania granic równego traktowania, a tym bardziej tworzenia przedziałów działowych. To ustawodawca ma zrealizować zasadę sprawiedliwości, a doktryna prawa podatkowego ma tylko pomóc w jej realizacji ${ }^{25}$. Oczywiście, swoboda ustawodawcy nie jest nieograniczona, gdyż nie może prowadzić do nieuzasadnionego traktowania podatników w odmienny sposób oraz pozbawiania ich praw, zwłaszcza wolności i własności ${ }^{26}$. Niemniej takie ujęcie sprawiedliwego równego traktowania prowadzi do bardzo dużej swobody ustawodawcy w zakresie określania kryteriów różnicowania sytuacji podatników.

Argument równego traktowania szybko upada, kiedy przechodzimy do dyskusji nad sprawiedliwością pionową i progresywnością. Wartości przestają być obiektywne, a pojawia się więcej argumentów słusznościowych i ocennych ${ }^{27}$ : dlaczego wybieramy opodatkowanie progresywne; jakie jest uzasadnienie dla zwiększonego opodatkowania, w tym czy celem państwa jest dokonywanie transferów społecznych; jakie powinny być przedziały

${ }^{22}$ C.E. Steuerle, And Equal (Tax) Justice for All?, [w:] Tax Justice: The Ongoing Debate, eds J.J. Thorndike, D.J. Ventry Jr., Washington 2002, s. 259.

23 A. Nita, op. cit., s. 18.

24 A. Gomułowicz, Zasada sprawiedliwości podatkowej, Warszawa 2001, s. 12-13.

25 Ibidem.

26 A. Gomułowicz, Zasada sprawiedliwości podatkowej w orzecznictwie Trybunału Konstytucyjnego. Aspekt materialny, Warszawa 2003, s. 30 i n.

${ }^{27}$ H. Stein, What's Wrong with the Federal Tax System?, [w:] U.S. Congress, Tax Revision Compendium of Papers on Broadening the Tax Base, t. 1, Washington 1959. 
skali oraz wysokość stawek podatkowych, w tym stawka maksymalna; kto zasługuje na preferencyjne opodatkowanie itd.

$\mathrm{W}$ zależności od poglądów politycznych preferuje się jeden $\mathrm{z}$ rodzajów sprawiedliwości. Zwolennicy państwa minimalistycznego i fundamentalnych praw i wolności osobistych jednostki będą kłaść nacisk na sprawiedliwość poziomą, a stronnicy państwa opiekuńczego na pionową ${ }^{28}$. Przy czym, co do zasady, nawet druga grupa nie kwestionuje równości poziomej, w dyskusji o sprawiedliwości pionowej przedkłada jednak jej wartości nad równość jednostki. W zależności od założenia, jakie prawa są fundamentem funkcjonowania państwa, możemy uzyskiwać diametralnie różne rezultaty.

\section{ZASADA EKWIWALENTNOŚCI A ZASADA ZDOLNOŚCI PŁATNICZEJ}

W doktrynie prawa podatkowego wymienia się dwie główne zasady opodatkowania podatkami dochodowymi: ekwiwalencji oraz zdolności płatniczej.

Teoria ekwiwalencji zakłada adekwatność świadczeń państwa w stosunku do ponoszonego ciężaru podatkowego. Przy czym u swoich źródeł służyła ona do wyższego opodatkowania osób zamożnych, albowiem państwo przede wszystkim im zapewniało bezpieczeństwo osobiste i ochronę majątku. Skoro posiadający majątek, którego zabezpieczeniem zajmowało się państwo, uzyskiwał wyższe korzyści, to musiał płacić wyższą daninę ${ }^{29}$.

Przyjmuje się, że zasada ekwiwalentności mogłaby stanowić podstawę do finansowania kosztów usług publicznych ${ }^{30}$. W momencie rozrostu funkcji państwa stało się jednak niemożliwe zmierzenie tej ekwiwalentności. Brak jest mierników korzyści z usług dostarczanych przez państwo ${ }^{31}$. Wiele usług publicznych nie jest nakierowanych na konkretnych użytkowników, ale służy wszystkim obywatelom, jak obrona czy polityka zagraniczna. Dlatego możemy mówić o odpłatności o charakterze ogólnym, co także eliminuje problem tych, którzy nie chcą płacić podatków, bo nie korzystają z usług publicznych. Sama przynależność do związku państwowego jest uzasadnieniem dla konieczności ponoszenia danin publicznoprawnych. Nie ma zatem znaczenia, czy podatnik czerpie z tego tytułu jakiekolwiek korzyści.

${ }^{28}$ Szerzej zob. R. Gwiazdowski, Sprawiedliwość a efektywność opodatkowania, Warszawa 2001, s. 24-64.

${ }^{29}$ A. Nita, op. cit., s. 19.

30 A. Gomułowicz, Zasada sprawiedliwości podatkowej, Warszawa 2001, s. 66.

31 A. Nita, op. cit., s. 20. 
Należy podkreślić, że stosując tę zasadę, niemożliwa stałaby się realizacja funkcji redystrybucyjnej ${ }^{32}$. Nie wolno tego aspektu pomijać - zasada ekwiwalentności nie jest przydatna dla realizacji funkcji państwa socjalne$\mathrm{go}^{33}$. Uniemożliwia ona realizację transferów socjalnych.

Z kolei zgodnie z założeniami teorii zdolności płatniczej wysokość opodatkowania winna być uzależniona od zdolności poniesienia ciężaru podatkowego, a tym samym dopuszcza ona różne opodatkowanie osób znajdujących się w odmiennych sytuacjach. Teoria zdolności płatniczej odrywa się całkowicie od ekwiwalentności świadczeń państwa, nawet na poziomie ogólnym. Podatnik, który korzysta w minimalnym zakresie (np. tylko z obronności), nie ma podstaw do żądania obniżenia swych świadczeń. Wysokość jego ciężarów uzależniona jest od jego sytuacji osobistej, często będącej wynikiem tylko i wyłącznie jego pracowitości i talentów. Zasada ta ignoruje zatem korzyści uzyskiwane przez podatnika, a pozwala na nałożenie ciężarów podatkowych $\mathrm{w}$ takiej proporcji, jak pozwala na to sytuacja osobista podatnika. Przy czym sytuację tę ustala się w odniesieniu do wysokości dochodu. Rosnąca podstawa opodatkowania nie zawsze oznacza lepszą sytuację osobistą podatnika, na to bowiem wpływa wiele czynników. Nie ma miejsca w niniejszym artykule na szerokie rozwinięcie tego zagadnienia, ale należy wskazać, że nie ma możliwości obiektywnego ustalenia sytuacji osobistej każdego z podatników.

Jednocześnie Państwo uzyskuje swobodę dysponowania dochodami podatkowymi, może je również wydatkować na inne cele niż świadczenie usług publicznych. Redystrybucja prowadzona jest przy tym według swobodnego uznania rządzących. Może to prowadzić do transferów od osoby znajdującej się w gorszej sytuacji osobistej niż osoba otrzymująca różnego rodzaju świadczenia od Państwa.

\section{AKSJOMAT ZASADY ZDOLNOŚCI PŁATNICZEJ}

We współczesnej doktrynie prawa podatkowego powszechnie przyjmuje się, że zasada zdolności płatniczej jest niekwestionowanym fundamentem, stając się treścią norm prawnych kształtujących wysokość obciążeń podatkowych.

32 A. Gomułowicz, Zasada sprawiedliwości podatkowej, Warszawa 2001, s. 66.

33 A. Krajewska, Dlaczego musimy płacić podatki?, [w:] Podatki. Przewodnik Krytyki Politycznej, Warszawa 2011, s. 29. 
Zwolennicy zasady zdolności płatniczej wskazują przy tym, że jest to paradygmat współczesnego prawa podatkowego już od czasów A. Smitha ${ }^{34}$, który rzekomo miał się opowiadać za progresywnym opodatkowaniem ${ }^{35}$. Można także spotkać poglądy odmienne, wskazujące na opowiadanie się przez niego raczej za teorią ekwiwalencji ${ }^{36}$. Wydaje się jednak, że A. Smith ${ }^{37}$ traktował obydwie zasady jako wzajemnie się uzupełniające. Nie można jednoznacznie przesądzić, że opowiadał się za jedną z nich ${ }^{38}$, lecz wskazywał jednocześnie na obydwie ${ }^{39}$. Można więc twierdzić, że widział on połączenie obu zasad poprzez dochód i związany z tym popyt na usługi publicz$n e^{40}$. Jest to o tyle zasadne, iż w jego czasach $z$ tradycyjnych usług państwa (obrona, sądy) w większym stopniu korzystali zamożni obywatele ${ }^{41}$. Jego wizja zdolności płatniczej wiedzie zatem do zasady ekwiwalencji. Dlatego należy stwierdzić, iż obrońcy zasady zdolności płatniczej nadają sformułowanej przez A. Smitha zasadzie równości inne znaczenie, niż miała ona za jego życia ${ }^{42}$.

Dopiero twórca tzw. liberalizmu socjalnego J.S. Mill wskazał na dominację zasady zdolności płatniczej ${ }^{43}$. Jego zdaniem sprawiedliwość wymaga różnych obciążeń podatkowych, które nakładają równą ofiarę absolutną dla nierównych dochodów. Ustrój społeczno-polityczny powinien być tak skonstruowany, aby zapewnić jak najwięcej szczęścia dla jak największej liczby ludzi. Jednocześnie zastrzegał, że po opodatkowaniu powinno zostać jak najwięcej dochodu, dlatego nie był zwolennikiem progresji podatkowej.

${ }^{34}$ Szerszą analizę zob. R. Gwiazdowski, Sprawiedliwość..., s. 76 i n.

35 A. Gomułowicz, J. Małecki, Podatki i prawo podatkowe, Poznań 1998, s. 22.

${ }^{36}$ E.K. Drozdowski, Zasada zdolności płatniczej a polski system podatkowy, Poznań 2018, s. 24.

37 „That the subjects of every State ought to contribute to the support of the government, as nearly as possible, in proportion to their respective abilities, that is in proportion to the revenue which they respective abilities, that is in proportion to the revenue which they respectively enjoy under protection of the State" (A. Smith, Inquiry into the Nature and Causes of the Wealth of Nations, London 1776).

38 Tak wskazują A. Gomułowicz i D. Mączyński w pracy Podatki i prawo podatkowe, Warszawa 2016, s. 54.

39 R.A. Musgrave, The future of fiscal policy: A Reassessment, Leuven 1978, s. 57.

40 R.A. Musgrave, Horizontal equity, once more, „National Tax Journal” 1990, t. 43, nr 2, s. 114.

${ }^{41}$ C.E. Steuerle, op. cit., s. 261-262.

${ }^{42}$ R. Gwiazdowski, Podatek progresywny i proporcjonalny. Doktrynalne przesłanki, praktyczne konsekwencje, Warszawa 2007, s. 95.

43 J.S. Mill, Principle of Political Economy, London 1848. 
W dalszej kolejności prace utylitarystów, w szczególności Johna Benthama, skupiające się na maksymalizacji szczęścia, prowadziły do konieczności redystrybucji dochodu. Skoro wraz ze wzrostem dochodu maleje jego użyteczność, to należy zwiększyć jego przydatność dla maksymalizacji użyteczności poprzez redystrybucję. Skutkiem stało się utożsamianie sprawiedliwości podatkowej z różnicowaniem pionowym, a zwłaszcza progresywnym opodatkowaniem. W późniejszym okresie do takich samych wniosków doszli komuniści, żądając wprowadzenia stawki $100 \%{ }^{44}$.

Na fali krytyki systemu społeczno-gospodarczego panującego w XIX w. powstawały kolejne teorie zwiększające rolę państwa, szczególnie poza obszarem tradycyjnych funkcji, jak zapewnienie bezpieczeństwa obywatelom. Zwiększały one rolę rządów w interwencjonizmie w celu korygowania nierówności społecznych. Podkreślano, że ograniczenie zasady równości i wolności uzasadniane jest dobrem ogółu, nadrzędnym w stosunku do dobra jednostki.

Kontynuując prace kameralistów, niemiecka szkoła Lorenza von Steina i Adolfa Wagnera podkreślała społeczne cele opodatkowania ${ }^{45}$. Uszczuplając majątek bogatych, system podatkowy pozwala korygować nierówności dochodowe. Wagner optował za progresją podatkową, ale połączoną ze specjalnymi obciążeniami dochodów nadzwyczajnych i posiadania majątku. Jednocześnie podkreślał konieczność różnicowania obciążeń w zależności od źródła oraz sposobu powstania dochodów, podkreślając preferencyjne opodatkowanie pracy. Nie miał jednak wątpliwości co do rosnącej roli państwa, wobec konieczności realizowania przez nie nowych funkcji w dobie rozwoju cywilizacyjnego. Państwo musiało zatem znaleźć odpowiednie dochody do realizacji celów, które samo sobie wyznaczyło.

Kolejnym przełomem w zmianie zasad opodatkowania był rozwój teorii zapoczątkowanych przez J. Keynesa ${ }^{46}$. O ile co do zasady uznawał on skuteczność gospodarki wolnorynkowej, to nie miał wątpliwości w odniesieniu do potrzeby ingerencji w sytuacjach kryzysu. Stał się ojcem chrzestnym interwencjonizmu, wzrostu roli państwa w gospodarce, ale także wprowadzania korekcji nierównych dochodów, czyli istnienia państwa dobrobytu. Podatki interesowały go głównie w zakresie zwiększenia popytu, który był głównym

${ }_{44}$ Również współcześni socjaliści reprezentują podobne poglądy, zob. T. Piketty, op. cit., s. 612 i n.

45 R. Gwiazdowski, Podatek progresywny i proporcjonalny..., s. 103-104.

46 J. Keynes, The General Theory of Employment, Interest and Money, London 1936; wydanie polskie: Ogólna teoria zatrudnienia, procentu i pieniądza, Warszawa 2003. 
celem jego teorii wzrostu. A opiekuńcze państwo dobrobytu to oparta na zasadzie zdolności płatniczej progresja podatkowa.

Zauroczony keynesizmem świat demokracji liberalnej wprowadzał bardzo wysokie stawki progresywnego podatku, które osiągały od 70\% do 91\%. Dodatkowo coraz więcej osób przechodziło do wyższych przedziałów skali podatkowej, co było również wynikiem zamrożenia progów podatkowych. Jednocześnie znacząco zwiększono transfery socjalne, np. w latach siedemdziesiątych wzrosły one ponad czterokrotnie ${ }^{47}$. Mimo to gospodarki liberalne popadały w coraz większe ograniczenie wzrostu gospodarczego. W latach siedemdziesiątych w krajach o wysokiej progresji średnie tempo wzrostu spadło poniżej $2 \%$, a czasami wręcz panowała stagnacja.

Tymczasem już na przełomie lat trzydziestych i czterdziestych tzw. szkoła austriacka, którą reprezentowali L. von Mises ${ }^{48}$ i F.A. von Hayek ${ }^{49}$, ostro potępiała interwencjonizm. Zdaniem pierwszego $\mathrm{z}$ autorów może on w krótkim czasie poprawić sytuację wybranych grup społeczeństwa, ale odbywa się to kosztem ogółu. Ponieważ takich grup jest wiele, to raz jedne zyskują, raz tracą kosztem kolejnych. Zresztą nie ma co ukrywać, iż zwolennicy interwencjonizmu to ludzie, którym się nie powiodło. Hayek podkreślał zresztą, że prowadzi to do nowożytnego niewolnictwa. Władca decyduje bowiem, komu dać, a komu zabrać.

W latach osiemdziesiątych XX w. posłuch zdobyły poglądy M. Friedmana oraz jego uczniów z tzw. szkoły chicagowskiej. Twierdzili oni, że najważniejszym składnikiem życia ekonomicznego jest wolność jednostek w podejmowaniu decyzji mających bezpośredni wpływ na sytuację, w jakiej się znajdują. Podatek dochodowy, jeśli w ogóle powinien istnieć, nie może służyć redystrybucji bogactwa. Nie powinien on bowiem przeszkadzać w rozwoju gospodarczym i kumulowaniu kapitału niezbędnego do inwestowania oraz tworzenia nowych miejsc pracy ${ }^{50}$. Służy on tylko rozrostowi aparatu rządowego, a jednocześnie wpływa negatywnie na gospodarkę rynkową, a tym samym powoduje destrukcję społeczeństwa.

${ }^{47}$ W. Bieńkowski, Reaganomika i jej wpływ na konkurencyjność gospodarki amerykańskiej, Warszawa 1995, s. 115-116.

${ }^{48}$ L. von Mises, Interwencjonizm, Kraków 2000.

49 J. Lewandowski, Neoliberałowie wobec współczesności, Gdynia 1991, s. 17 i n.

50 Te zasady potwierdziły się m.in. w krajach byłego bloku komunistycznego, które zanotowały szybki wzrost gospodarczy w okresie niskiego opodatkowania, często podatkiem liniowym. 
Poważny wpływ na zakwestionowanie idei keynesowskich miały także prace A. Rand ${ }^{51}$. Rząd jest tylko arbitrem w konfliktach między jednostkami. Absolutnie nie do zaakceptowania jest interwencja rządu w stosunki społeczno-gospodarcze w celu ich korygowania. Jeżeli raz przyzwolimy na dostarczanie bezpłatnych usług zamiast działania gospodarki rynkowej, to sfera ta szybko zacznie się powiększać, a rząd zacznie ingerować w coraz większy obszar naszego życia ${ }^{52}$. Jednak ograniczona władza nie dawałaby rządzącym tylu możliwości uszczęśliwiania obywateli. Dlatego politycy tak bardzo potrzebują poparcia dla idei państwa socjalnego ${ }^{53}$.

Współcześnie można także spotkać zwolenników interwencjonizmu, w tym wysokiego, dochodzącego nawet do $80 \%$, opodatkowania dochodu. Słynne stały się już prace Th. Piketty, zwłaszcza jego kontrowersyjne dzieło Kapitał XXI wieku ${ }^{54}$. Jego teorie są jednak nie do utrzymania, bo opierają się na błędnych przesłankach. Kapitalną polemikę stanowi praca R. Gwiazdowskiego ${ }^{55}$.

\section{OBOWIĄZUJĄCE DOGMATY OPODATKOWANIA DOCHODU}

Jak wynika z powyżej opisanej historii opodatkowania oraz rozwoju teorii podatkowych i doktryn polityczno-społecznych, współczesne podatki dochodowe rozkwitły w pierwszej połowie XX w., co miało związek zwłaszcza z wybuchem wojen światowych. Konieczność finansowania wydatków wojennych była idealnym uzasadnieniem najpierw dla samego wprowadzenia tego typu podatku, w rezultacie zaś dla zwiększenia stawek podatkowych oraz konieczności proporcjonalnego, a w konsekwencji progresywnego opodatkowania, co uzasadniano zasadą kompensacyjną ${ }^{56}$. Po pierwsze, osoby, które nie brały bezpośredniego udziału w walce, musiały w większym stopniu dołożyć się do kosztów wojennych. Po drugie, często wojna oznaczała dla nich dodatkowe korzyści związane z produkcją wojenną. Z kolei po wojnie pojawiły się argumenty odwołujące się do

51 A. Rand, Cnota egoizmu, Warszawa 1987, wyd. 2: Poznań 2000.

52 Warto zwrócić uwagę na pracę o znaczeniu fundamentalnym: R. Nozick, Anarchy, State, and Utopia, New York 2013.

53 E. von Kuehnelt-Leddihn, Demokracja - opium dla ludu, Warszawa 2012, s. 73 i n.

54 T. Piketty, op. cit.

${ }_{55}$ R. Gwiazdowski, Równość i (nie)sprawiedliwość. Dlaczego Piketty nie lubi bogatych?, Warszawa 2016.

${ }^{56}$ K. Scheve, D. Stasavage, op. cit., s. 5. 
wyrównywania szkód poniesionych przez uczestników, na co lepiej zarabiający powinni łożyć więcej57.

Należy zatem podkreślić, że po II wojnie światowej wskazywano na różnorakie argumenty słusznościowe mające uzasadnić progresywne stawki: opodatkowanie kolaborantów we Francji, wspólne poniesienie kosztów w Niemczech czy zadośćuczynienie wysiłku walczących o wolność w Wielkiej Brytanii ${ }^{58}$. Teoria kompensacji zastąpiła dziewiętnastowieczne poglądy o konieczności zwiększonego ciężaru dla osób, które w większym stopniu korzystają z funkcji państwa. Nie można było dalej odwoływać się do zasady ekwiwalencji, albowiem z usług publicznych korzystało coraz więcej osób, a w XXI w. doszliśmy do sytuacji, gdy są one najbardziej potrzebne osobom o niższych dochodach (szkolnictwo, służba zdrowia, publiczna komunikacja itp. $)^{59}$.

Po zakończeniu odbudowy powojennych zniszczeń, kiedy teoria kompensacyjna nie znajdowała już zastosowania, potrzebne było inne uzasadnienie dla zróżnicowania opodatkowania w układzie wertykalnym. Są co najmniej trzy powody, dla których wyższe opodatkowanie bogatych jest akceptowalne ${ }^{60}$.

Pierwszy powód jest taki, że w ocenie wyborców sprawiedliwe jest opodatkowanie lepiej zarabiających. Intuicyjnie akceptują oni teorię malejącej krańcowej użyteczności dochodu. Ma to pozwolić nie tylko na świadczenie usług publicznych dla wszystkich obywateli, ale także na zapewnienie środków na transfery socjalne.

Drugi powód związany jest z przekonaniem, że nie wszyscy mają równe szanse. Dlatego osoby osiągające niższe dochody chętnie akceptują tezę, iż osoby bogatsze nie osiągnęły takiego sukcesu w wyniku uczciwej pracy, zdolności czy po prostu szczęścia. W niektórych krajach może to być zresztą prawdziwe twierdzenie. Niejednokrotnie duże fortuny powstawały w wyniku korupcji lub układów, lecz w większości państw OECD jest to współcześnie raczej marginalne źródło dochodów. W wielu z nich (np. w Polsce) panuje jednak przekonanie, że nie wszyscy mają zapewnione równe szanse. Ponownie redystrybucja dochodów ma umożliwić takie wyrównanie oraz lepsze warunki życiowe, ale także rozwoju osobistego.

57 Ibidem, s. 54-92.

58 Ibidem, s. 187 i n.

59 Czasami poszukuje się jednak uzasadnienia, iż to osoby zamożne więcej korzystają z usług publicznych, podając jako przykład usługi kulturalne (teatr, opera) - A. Krajewska, op. cit., s. 27.

${ }^{60}$ K. Scheve, D. Stasavage, op. cit., s. 15. 
Powód trzeci wiąże się z sytuacją, gdy nierówności są tak duże, że zagrażają systemowi politycznemu. Istnieje wówczas ryzyko uznania, iż system jest oligarchiczny bądź sterowany przez najbogatsze elity. Obywatele, albo legalnie w drodze wyborów, albo w drodze siłowej, mogą doprowadzić do obalenia takiego systemu. W miarę wzrostu stopnia nierówności społecznych rośnie poparcie dla progresji podatkowej i jej funkcji redystrybucyjnej.

W debacie o podatkach dochodowych wskazuje się także, że bez nich nie byłoby sprawiedliwe rozłożenie ciężarów podatkowych. Jednak określenie sprawiedliwego wkładu każdego obywatela było przedmiotem wielu dyskusji i analiz ${ }^{61}$. Trudno zatem odnieść się do tego w niniejszej publikacji.

Dla uzasadnienia wyższego opodatkowania początkowo nie używano argumentów redystrybucyjnych. W niektórych krajach, np. w neutralnej Szwecji, już w trakcie II wojny światowej wykorzystywano argumenty kompensacyjne do zbudowania poparcia dla polityki redystrybucyjnej ${ }^{62}$. Zwiększone dochody publiczne wspomagały jednak debatę na temat funkcji redystrybucyjnej podatków dochodowych. Doprowadziło to do akceptacji progresywnego opodatkowania, jako środka redystrybucji dochodów w państwie dobrobytu, a niektórzy przyjmują nawet te zasady za dogmat współczesnej filozofii politycznej.

Nie można nie zauważyć, że rozwój koncepcji różnicowania pionowego immanentnie związany jest z państwem dobrobytu i koniecznością dokonywania transferów społecznych. Podnoszone argumenty są bardzo zróżnicowane, ale prowadzą do tego samego wniosku: dochód powinien być bardziej sprawiedliwie rozłożony, wyższe opodatkowanie osób bogatszych nie spowoduje zaś znacznego pogorszenia ich sytuacji, a może pomóc osobom o niższych dochodach. Wpływy z wysokiego opodatkowania osób najbogatszych stanowią jednak ułamek dochodów budżetowych, a mogą mieć negatywny wpływ na funkcjonowanie gospodarki ${ }^{63}$. Co ciekawe, nikt nie wykazał także, jak maleje użyteczność dochodu, a zwłaszcza gdzie jest ostateczna granica ${ }^{64}$.

${ }^{61}$ Fairness in Taxation, red. A.M. Maslove, Ontario 1993; J.J. Thorndike, D.J. Ventry Jr., The ongoing debate. Tax justice, Washington 2002; S.M. Sheffrin, Tax fairness...; J.M. Buchanan, R.A. Musgrave, Finanse publiczne a wybór publiczny, Warszawa 2005; A. Gomułowicz, Zasada sprawiedliwości podatkowej, Warszawa 2001.
${ }^{62}$ K. Scheve, D. Stasavage, op. cit., s. 189.
${ }^{63}$ R. Gwiazdowski, Sprawiedliwość..., s. 80 i n.
${ }^{64}$ C.E. Steuerle, op. cit., s. 265. 


\section{Podsumowanie - KOMU POTRZEBNy JEST PODATEK DOCHODOWY}

Każdy podatek ma w jakimś sensie charakter polityczny, bowiem to parlament decyduje jakie obciążenia podatkowe zostaną wprowadzone. Jednak podatek dochodowy stał się narzędziem walki politycznej. „Partie muszą nieustannie szukać nowych obszarów, w których mogłyby funkcjonować jako dobroczyńcy i przenikać do nich za pośrednictwem struktur państwowych. Przekupiony w ten sposób obywatel stopniowo oddaje w ręce państwa odpowiedzialność za samego siebie i wolność osobistą, poświęcając ją dla równości, poczucia bezpieczeństwa i (egalitarnego) dobrobytu" ${ }^{2}$. Państwo takie odrzuca zatem liberalizm, czyli wolność, która niesie za sobą niepewność. W zamian, w imię bezpieczeństwa socjalnego, zaczyna ingerować we wszystkie możliwe obszary życia obywateli. Jak twierdził F. Hayek, ideał demokracji, który pierwotnie zmierzał do wyeliminowania arbitralnej władzy, stał się usprawiedliwieniem nowego rodzaju arbitralnej władzy ${ }^{66}$. W tym celu politycy poszukują dodatkowych dochodów budżetowych, które finansują rosnące wydatki, zwłaszcza transfery socjalne.

Z drugiej jednak strony różnego rodzaju grupy mogą skutecznie lobbować za przywilejami. Choć najwyższe stawki podatkowe mogą być stosunkowo wysokie, to jednak efektywna stopa opodatkowania dla najbogatszych wcale nie musi odbiegać od opodatkowania innych grup podatników. Słynne stało się już wystąpienie W. Buffetta, który stwierdził, że jego sekretarka płaci dwa razy wyższy podatek niż on sam ${ }^{67}$.

Dlatego współczesny podatek dochodowy, oparty na arbitralnych decyzjach władcy podatkowego, nie będzie zgodny z zasadą sprawiedliwego opodatkowania ani w ujęciu subiektywnym, ani obiektywnym. Podatek ten jest jednak dla polityków, którzy jednym zabierają, a innym dają. Dlatego opodatkowanie dochodu, zwłaszcza według stawek progresywnych, oraz transfery socjalne stały się immanentną częścią walk politycznych.

$\mathrm{Z}$ tego powodu w żadnym kraju tzw. demokracji liberalnej nie udało się przeprowadzić choćby rzetelnej dyskusji o potrzebie i zasadach opodatkowania, zwłaszcza dochodów osób fizycznych.

${ }^{65}$ E. Von Kuehnelt-Leddihn, op. cit., s. 56.

66 F. Hayek, The Constitution of Liberty, Chicago 1960, s. 103-117.

67 „Debbie works just as hard as I do and she pays at twice the rate I pay”, Warren Buffett: In tax war, rich people have „nuclear bomb”, https://www.cbsnews.com/news/ warren-buffett-in-tax-war-rich-people-have-nuclear-bomb/ (dostęp: 15.08.2019). 


\section{BIBLIOGRAFIA}

Bieńkowski W., Reaganomika i jej wpływ na konkurencyjność gospodarki amerykańskiej, Warszawa 1995.

Buchanan J.M., Musgrave R.A., Finanse publiczne a wybór publiczny, Warszawa 2005.

Drozdowski E.K., Zasada zdolności płatniczej a polski system podatkowy, Poznań 2018.

Fairness in Taxation, red. A.M. Maslove, Ontario 1993.

Gajl N., Modele podatkowe. Podatki dochodowe, Warszawa 1995.

Głuchowski J., Oazy podatkowe, Warszawa 1996.

Goldberg J., Why 'Tax the Rich' Demands Are So Unreasonable, „National Review” 12.04.2019.

Gomułowicz A., Zasada sprawiedliwości podatkowej, Warszawa 2001.

Gomułowicz A., Zasada sprawiedliwości podatkowej w orzecznictwie Trybunału Konstytucyjnego. Aspekt materialny, Warszawa 2003.

Gomułowicz A., Małecki J., Podatki i prawo podatkowe, Poznań 1998.

Grapperhaus F.H.M., Opowieści podatkowe, Torun 2000.

Gwiazdowski R., Podatek progresywny i proporcjonalny. Doktrynalne przesłanki, praktyczne konsekwencje, Warszawa 2007.

Gwiazdowski R., Równość i (nie)sprawiedliwość. Dlaczego Piketty nie lubi bogatych?, Warszawa 2016.

Gwiazdowski R., Sprawiedliwość a efektywność opodatkowania, Warszawa 2001.

Hayek F., The Constitution of Liberty, Chicago 1960.

Keynes J., The General Theory of Employment, Interest and Money, London 1936; wyd. polskie: Ogólna teoria zatrudnienia, procentu i pieniadza, Warszawa 2003.

Krajewska A., Dlaczego musimy płacić podatki?, [w:] Podatki. Przewodnik Krytyki Politycznej, Warszawa 2011.

Kuehnelt-Leddihn von E., Demokracja - opium dla ludu, Warszawa 2012.

Kwaśnicki W., Z historii podatku dochodowego, http://kwasnicki.prawo.uni.wroc.pl/ todownload/Historia\%20podatku\%20doch.pdf (dostęp: 15.08.2019).

Leconte M., Raińczuk M., Konwencja Wielostronna (BEPS działanie nr 15) - omówienie najistotniejszych zagadnien, „Monitor Podatkowy” 2017, nr 5.

Lewandowski J., Neoliberałowie wobec wspótczesności, Gdynia 1991.

Mariański A., Strzelec D., Podatki dochodowe, [w:] Zagadnienia ogólne prawa podatkowego, red. W. Nykiel, M. Wilk, Łódź 2014.

Mastalski R., Prawo podatkowe, Warszawa 2018.

Mill J.S., Principle of Political Economy, London 1848.

Mises von L., Interwencjonizm, Kraków 2000.

Musgrave R.A., The Future of Fiscal Policy: A Reassessment, Leuven 1978.

Musgrave R.A., Horizontal equity, once more, „National Tax Journal” 1990, t. 43, nr 2.

Nita A., Teoretyczne i normatywne wyznaczniki sprawiedliwego opodatkowania, „Toruński Rocznik Podatkowy" 2013.

Nozick R., Anarchy, State, and Utopia, New York 2013.

Nykiel W., Mariański A., Komentarz do art. 217, [w:] Konstytucja RP, t. 2: Komentarz do art. 87-243, red. M. Safjan, L. Bosek, Warszawa 2016.

Opodatkowanie działalności gospodarczej w Polsce, red. A. Mariański, A. Krajewska, A. Nowak-Piechota, M. Wilk, Warszawa 2016. 
Piketty T., Kapitał w XXI wieku, Warszawa 2015.

Polskie prawo podatkowe, red. W. Nykiel, Warszawa 2018.

Prawo podatkowe przedsiębiorców, red. H. Litwińczuk, P. Karwat, A. Kaznowski, W. Pietrasiewicz, K. Tetłak, Warszawa 2013.

Rabushka A., Od Adama Smitha do bogactwa Ameryki, Warszawa 1996.

Rand A., Cnota egoizmu, Warszawa 1987, wyd. 2: Poznań 2000.

Scheve K., Stasavage D., Taxing the Rich: A History of Fiscal Fairness in the United States and Europe, Princeton 2016.

Sheffrin S.M., Tax Fairness and Folk Justice, Cambridge 2013.

Smith A., Inquiry into the Nature and Causes of the Wealth of Nations, London 1776.

Stein H., What's Wrong with the Federal Tax System?, [w:] U.S. Congress, Tax Revision Compendium of Papers on Broadening the Tax Base, t. 1, Washington 1959.

Steuerle C.E., And Equal (Tax) Justice for All?, [w:] Tax Justice: The Ongoing Debate, eds J.J. Thorndike, D.J. Ventry Jr., Washington 2002.

Thorndike J.J., Ventry Jr. D.J, The ongoing debate. Tax justice, Washington 2002.

Tipke K., Lang J., Steuerrecht, Köln 1991.

Wach K., Systemy podatkowe krajów Unii Europejskiej, Warszawa 2005.

Zajdler R., Opodatkowanie dochodów osób fizycznych $w$ regulacjach prawnych Unii Europejskiej, Warszawa 2002.

\section{SHORT STORY OF TAXATION OF WEALTHY PERSONS - WHERE THE ABILITY TO PAY PRINCIPLE CAME FROM}

Summary. This article analyzes the relatively short history of income taxation. The source of this type of tax is particularly interesting. Progressive taxation is strongly connected with compensation rules that were implemented during and after a number of wars. In the post-World War II period, income taxation was connected with redistribution rules. Currently, the ability-to-pay rule is a fundamental rule for this form of taxation. As a consequence, income tax is now very much a political tax.

Keywords: income taxation, progressive tax, ability-to-pay rule 